\title{
HUBUNGAN ANTARA KANDUNGAN NITRAT DAN FOSFAT DENGAN KELIMPAHAN FITOPLANKTON DI SUNGAI BREMI KABUPATEN PEKALONGAN
}

\author{
Menur Rumanti, Siti Rudiyanti ${ }^{I}$, Mustofa Niti Suparjo \\ Program Studi Manajemen Sumberdaya Perairan, Jurusan Perikanan \\ Fakultas Perikanan dan Ilmu Kelautan, Universitas Diponegoro
}

\begin{abstract}
ABSTRAK
Kelimpahan fitoplankton di suatu perairan tergantung pada kandungan zat hara di perairan antara lain nitrat dan fosfat. Konsentrasi nitrat dan fosfat di suatu perairan dipengaruhi oleh kualitas perairan dan buangan limbah yang masuk ke dalam suatu perairan sungai. Sungai Bremi mengalir di sepanjang pemukiman penduduk yang sebagian besar bekerja sebagai buruh batik. Buangan limbah domestik dan industri tersebut dapat mempengaruhi kandungan nitrat dan fosfat. Kandungan nitrat dan fosfat dapat mempengaruhi keberadaan fitoplankton. Tujuan penelitian ini adalah untuk mengetahui kandungan nitrat dan fosfat, kelimpahan fitoplankton serta hubungan antara nitrat dan fosfat dengan kelimpahan fitoplankton di Sungai Bremi. Penelitian ini dilaksanakan pada bulan Mei-Juni 2013.

Materi yang digunakan dalam penelitian ini adalah air sampel untuk uji nitrat dan fosfat serta sampel fitoplankton yang berasal dari Sungai Bremi. Metode yang digunakan adalah survei lapangan dengan teknik pengambilan sampel secara purposive sampling. Kegiatan sampling dilakukan sebanyak 2 kali dengan interval waktu selama 3 minggu. Pengambilan sampel dilakukan pada 3 stasiun yang berbeda. Masingmasing stasiun terdiri dari 3 titik. Pengambilan sampel plankton menggunakan plankton net. Sampel plankton diawetkan menggunakan lugol iodine 1-2 tetes kemudian diidentifikasi di laboratorium. Uji kandungan nitrat dan fosfat dilakukan dengan skala laboratorium. Analisa data dilakukan menggunakan software SPSS 16.

Hasil penelitian menunjukkan kandungan nitrat di Sungai Bremi berkisar antara 0,81 mg/l - 0,99 $\mathrm{mg} / \mathrm{l}$. Kandungan nitrat tergolong rendah sehingga kurang optimal bagi pertumbuhan fitoplankton. Kandungan fosfat berkisar antara $0,90 \mathrm{mg} / \mathrm{l}-1,35 \mathrm{mg} / \mathrm{l}$. Kandungan fosfat tergolong tinggi namun masih dapat ditolerir oleh fitoplankton. Kelimpahan fitoplankton berkisar antara 1324 ind/1 - 2444 ind/l. Perolehan nilai $r$ sebesar 0,774 artinya antara kandungan nitrat dan fosfat dengan kelimpahan fitoplankton memiliki hubungan yang erat.
\end{abstract}

Kata kunci : Nitrat dan Fosfat, Kelimpahan Fitoplankton, Sungai Bremi

\section{ABSTRACT}

Phytoplankton abundance in a water depends on material contents of the waterway such as nitrate and phosphate. The concentration of nitrate and phosphate in water is influenced by waters quality and waste effluents that goes into these water. Bremi river flows along the residential area that mostly have batik home industry by which their domestic and industry waste effluent to the river. The waste could affect nitrate and phosphate contents in the water that could also affect the existence of phytoplankton. The purpose of this research were to find out thecontent of nitrates and phosphates, the abundance of phytoplankton and the relationship between nitrate and phosphate to abundance of phytoplankton in river Bremi. The research was conducted in May - June 2013.

Material used in research was water samples and sample of phytoplankton derived from the Bremi River. Methods used field survey with purposive technique sampling. The activity of sampling done in 2 times with a interval time three weeks. Sampling was carried out in the waters of the Bremi River on 3 different stations, each station consists of 3 points. Collection of phytoplankton sample using plankton net. Phytoplankton samples preserved using 1-2 drops lugol's iodine before identified in the laboratory. Water samplesto be tested it is nitrate and phosphate contents in laboratory scale. Data analysis research was done using software SPSS 16.

The result showed that content of nitrate in the Bremi River ranges between $0,81 \mathrm{mg} / \mathrm{l}-0,99 \mathrm{mg} / \mathrm{l}$. That classified as low so for the growth of phytoplankton so less optimal. Phosphat content ranges between $0,90 \mathrm{mg} / \mathrm{l}-1,35 \mathrm{mg} / \mathrm{l}$. Classified quite high but still can be tolerated by the phytoplankton. The abundance of phytoplankton ranges from 1324 ind/l- 2444 ind/l. The correlation between nitrate and phosphate contents to phytoplankton abundance have $r$ value of 0,774 , it is means have a close relation.

Keywords: Nitrate and Phosphate, Phytoplankton Abundance, River Bremi 


\section{Pendahuluan}

Sungai merupakan ekosistem yang penting bagi kehidupan makhluk hidup dan lingkungan sekitarnya. Sungai memberi manfaat bagi kehidupan manusia di sekitarnya serta kehidupan organisme di dalam perairan. Peranan sungai bagi aktivitas manusia berkaitan dengan kehidupan organisme. Adanya aktivitas manusia yang memanfaatkan perairan sungai tidak hanya berdampak bagi kehidupan organisme namun bagi kualitas air sungai tersebut.

Wilayah Kabupaten Pekalongan dialiri oleh beberapa sungai, salah satunya adalah Sungai Bremi. Sungai yang mengalir sepanjang $\pm 9 \mathrm{~km}$ ini berada di sekitar pemukiman warga yang padat penduduk dengan pekerjaan sebagai buruh batik. Aktivitas warga di sekitar aliran sungai memegang peran penting dalam mempengaruhi kondisi perairan Sungai Bremi. Limbah hasil aktivitas warga berasal dari kegiatan rumah tangga yang berupa limbah domestik, limbah industri batik yang masuk ke dalam aliran Sungai Bremi berpengaruh terhadap kondisi perairan dan kehidupan organisme. Buangan limbah tersebut berdampak terhadap kualitas perairan, hal tersebut diduga mempengaruhi kandungan nitrat dan fosfat. Kandungan nitrat dan fosfat di perairan berpengaruh terhadap keberadaan dan pertumbuhan fitoplankton.

Bentuk senyawa nitrogen yang paling dominan di perairan alami adalah ion nitrat (NO3-) dan sangat penting bagi pertumbuhan tanaman dan alga. Senyawa ini dihasilkan dari proses oksidasi sempurna senyawa nitrogen di perairan. Nitrifikasi merupakan proses oksidasi yang penting dalam siklus nitrogen (Effendi, 2003).

Fosfat merupakan elemen penting yang dibutuhkan untuk menopang kehidupan di perairan. Fosfat berasal dari erosi tanah, buangan industri, buangan kotoran hewan serta pelapukan batuan. Sebagian besar pencemaran yang disebabkan oleh fosfor berasal dari adanya senyawa deterjen di perairan (Yudya, 1991).

Fitoplankton dapat dijadikan indikator biologi yang dapat menentukan kualitas perairan baik melalui pendekatan keragaman spesies maupun spesies indikator. Fitoplankton sebagai indikator biologis bukan saja menentukan tingkat kesuburan perairan, tetapi juga fase pencemaran yang terjadi dalam perairan. (Elfinurfajri, 2009).

Kandungan zat hara di lingkungan perairan memiliki dampak positif, namun pada tingkatan tertentu juga dapat menimbulkan dampak negatif. Dampak positifnya adalah adanya peningkatan produksi fitoplankton dan total produksi ikan sedangkan dampak negatifnya adalah terjadinya penurunan kandungan oksigen di perairan, serta memperbesar potensi muncul dan berkembangnya jenis fitoplankton berbahaya yang lebih umum dikenal dengan istilah Harmful Algal Blooms atau HAB (Gypens et al, 2009 dalam Risamasu dan Prayitno, 2011).

Tujuan penelitian ini adalah untuk mengetahui mengetahui kandungan nitrat, fosfat dan kelimpahan fitoplankton di Sungai Bremi Kabupaten Pekalongan, dan mengetahui hubungan antara kandungan nitrat dan fosfat dengan kelimpahan fitoplankton di Sungai Bremi Kabupaten Pekalongan. Penelitian ini dilaksanakan pada bulan Mei-Juni 2013 di perairan Sungai Bremi Kabupaten Pekalongan. Kandungan nitrat dan fosfat dianalisis dengan skala laboratorium. Identifikasi fitoplankton dilakukan di Laboratorium Manajemen Sumberdaya Perairan, Fakultas Perikanan dan Ilmu Kelautan, Universitas Diponegoro.

\section{Materi dan Metode Penelitian}

\section{A. Materi Penelitian}

Materi yang digunakan dalam penelitian ini adalah air sampel dan sampel fitoplankton di perairan Sungai Bremi Kabupaten Pekalongan. Alat-alat yang digunakan dalam penelitian ini adalah secchi disk untuk mengukur kecerahan, bola arus untuk mengukur kecepatan arus, Water Quality Checkeruntuk mengukur $\mathrm{pH}$, DO dan suhu perairan, tongkat skala untuk mengukur kedalaman, Plankton net no. 25 untuk menyaring fitoplankton botol sampel sebagai wadah sampel air dan sampel fitoplankton, buku identifikasi plankton untuk mengidentifikasi fitoplankton, sedgewick rafter untuk menghitung fitoplankton, mikroskop untuk mengamati fitoplankton, pipet tetes untuk mengambil sampel dalam botol, ember plastik untuk mengambil sampel air, cool untuk menyimpan sampel air, kertas label untuk memberi tanda di botol sampel, alat tulis untuk mencatat data, kalkulator untuk menghitung data, kamera untuk mendokumentasikan penelitian dan GPS untuk mengetahui posisi lokasi. Bahan yang digunakan adalah sampel air untuk pengamatan, sampel fitoplankton untuk pengamatan dan lugol iodine untuk mengawetkan sampel fitoplankton.

\section{B. Metode Penelitian}

Metode yang digunakan dalam Penelitian ini adalah survei lapangan. Menurut Suharto dan Miryanti (2003), metode survei lapangan merupakan metode penelitian yang dilakukan untuk memperoleh fakta yang terdapat di lapangan dan mencari informasi yang faktual. Metode ini dilakukan pada sekumpulan obyek dan berasumsi bahwa obyek yang diteliti telah mewakili populasi yang diamati.

\section{Metode Pengumpulan Data}

Penentuan titik sampling dilakukan dengan teknik purposif sampling. Menurut Fachrul (2007), metode purposive sampling merupakan metode yang dilakukan dengan pertimbangan terlebih dahulu. 
Stasiun pengambilan sampel dipilih dengan melihat kondisi perairan dengan harapan representatif antara faktor lingkungan dan kelimpahan fitoplankton.

\section{Teknik pengambilan sampel}

Pengambilan sampel air danfitoplankton dilakukan sebanyak 2 kali dengan interval waktu selama 3 minggu. Sampling dilakukan pada 3 stasiun. Setiap stasiun memiliki 3 titik sampling dan setiap titik sampling dilakukan pengambilan sampel dengan cara komposit Stasiun I merupakan daerah yang diperkirakan tidak terlalu banyak menerima buangan limbah. Stasiun II di bagian tengah sungai berjarak 4 kilometer dari stasiun I yang merupakan daerah perairan yang dekat dengan pusat pembuangan limbah industri dan domestik sehingga diperkirakan menerima masukan buangan limbah yang paling berat. Stasiun III berada di dekat muara sungai yang lokasinya berjarak 3 kilometer dari stasiun II. Stasiun ini merupakan daerah yang masih terkena dampak masukan buangan limbah karena pengaruh pasang surut dan berada di dekat muara.

\section{a. Sampel air}

Teknik pengambilan sampel air dilakukan dengan cara sebagai berikut:

1. Mengambil sampel air untuk uji nitrat dan fosfat dilakukan dengan mengkompositkan sampel air tersebut ke dalam ember bervolume $10 \mathrm{~L}$ tidak penuh. Sampel air di ambil pada 3 sub titik yang telah ditentukan kemudian air sampel tersebut dikomposit;

2. Menyimpan air sampel yang telah didapat dalam cool box; dan

3. Menganilisis kandungan nitrat dan fosfat air sampel di laboratorium.

b. Sampel fitoplankton

Pengambilan sampel fitoplakton dilakukan sesuai stasiun dan titik sampling yang telah ditentukan.

Teknik pengambilan sampel plankton dilakukan dengan cara sebagai berikut:

1. Mengambil air sampel menggunakan ember bervolume $10 \mathrm{~L}$ sebanyak $10 \mathrm{kali}$. Sampel air di ambil pada 3 sub titik yang telah ditentukan maka total sampel air yaitu $300 \mathrm{~L}$, dengan total pengambilan sebanyak 30 kali. Lalu sampel air pada ketiga sub titik dikomposit.

2. Menyaring air sampel menggunakan plankton net, air sampel sebanyak 300 liter disaring untuk menghasilkan $60 \mathrm{ml}$ sampel plankton; dan

3. Mengawetkan sampel menggunakan lugol iodine sebanyak $1-2$ tetes

c. Pengukuran parameter pendukung kualitas perairan

Teknik pengukuran parameter kualitas air dilakukan pada 3 stasiun di tiap titik sampling yang telah ditentukan seperti pengambilan sampel fitoplakton dan air. Cara pengukuran parameter kualitas air antara lain adalah sebagai berikut:

1. Mengukur kecerahan perairan menggunakan piringan secchi disk pada setiap titik sampling kemudian mencatat hasilnya;

2. Mengukur kedalaman perairan menggunakan tongkat skala pada setiap titik sampling kemudian mencatat hasilnya;

3. Mengukur kecepatan arus menggunakan bola aruspada setiap titik sampling dan mencatat hasilnya;

4. Mengukur $\mathrm{pH}, \mathrm{DO}$ dan suhu perairan menggunakan Water Quality Checker pada setiap titik sampling kemudian mencatat hasilnya;

5. Mengukur $\mathrm{BOD}_{5}$ dengan skala laboratorium menggunakan sampel air sebanyak $600 \mathrm{ml}$; dan

6. Mengukur COD dengan skala laboratorium menggunakan sampel air sebanyak $600 \mathrm{ml}$

\section{Analisa Data}

a. Analisa nitrat dan fosfat

Kandungan nitrat dan fosfat yang terdapat pada sampel air diujikan di laboratorium.

\section{b. Identifikasi fitoplankton}

Identifikasi fitoplankton dilakukan dengan analisa laboratorium menggunakan buku kunci identifikasi plankton Toshihiko (1964). Penghitungan fitoplankton menggunakan mikroskop dengan perbesaran 10 x 10 . Sampel diletakkan di atas sedgwick rafter 50 × $20 \mathrm{~mm}$.

\section{c. Kelimpahan fitoplankton}

Perhitungan kelimpahan fitoplankton per liter menggunakan formulasi APHA (1998) dalam Pirzan dan Pong-Masak (2008), yaitu menggunakan rumus:

$$
\mathbf{N}=\frac{T}{L} x \frac{P}{p} x \frac{V}{v} \times \frac{l}{w}
$$

Keterangan:

$\mathrm{N}$ : Jumlah plankton per liter

$\mathrm{T}$ : Luas gelas penutup $\left(\mathrm{mm}^{2}\right)$

$\mathrm{L}$ : Luas lapang padang $\left(\mathrm{mm}^{2}\right)$

$\mathrm{P}$ : Jumlah plankton yang tercatat 
$\mathrm{p}$ : Jumlah lapangan padang yang diamati (10)

$\mathrm{V}$ : Volume sampel plankton yang tersaring $(\mathrm{ml})$

$\mathrm{v}:$ : Volume plankton di bawah gelas penutup $(\mathrm{ml})$

$\mathrm{w}$ : Volume sampel plankton yang tersaring

d. Indeks keanekaragaman (H')

Mengetahui keanekaragaman fitoplankton digunakan persamaan indeks Shannon-Wiener (Basmi, 1999 dalam Fachrul, 2007), yaitu sebagai berikut:

$$
\text { H' } \quad=\sum_{i=1}^{s} p i \ln p i
$$

Keterangan :

$\mathrm{H}^{\prime}=$ Indeks keanekaragaman

$\mathrm{pi}=\mathrm{ni} / \mathrm{N}$

$\mathrm{ni}=$ Jumlah individu jenis ke- $\mathrm{i}$

$\mathrm{N}=$ Jumlah total individu

Kisaran nilai indeks keanekaragaman dapat diklasifikasikan sebagai berikut:

$\mathrm{H}^{\prime}<1=$ Komunitas biota tidakstabil

$1<\mathrm{H}^{\prime}<3$ = Stabilitas komunitas biota sedang

$\mathrm{H}^{\prime}>3$ = Stabilitas komunitas biota dalam kondisi prima (stabil)

\section{e. Indeks keseragaman (E')}

Indeks keseragaman digunakan untuk menunjukkan sebaran fitoplankton

dalam suatu komunitas. Menurut Fachrul (2007), indeks keseragaman juga dihitung dengan formula sebagai berikut:

Keterangan :

$$
\mathbf{E}=\frac{H^{\prime}}{H \max }=\frac{H^{\prime}}{\ln s}
$$

$\mathrm{E}=$ Indeks keseragaman

$\mathrm{H}^{\prime}=$ Indeks keanekaragaman Shannon-Wiener

Hmaks $=\ln \mathrm{s}$ (indeks keanekaragaman maksimum)

$\mathrm{s}=$ Jumlah genus yang ditemukan

Nilai indeks berkisar antara $0-1 . \mathrm{E}=0-0,5$, menunjukkan bahwa pemerataan antar genera rendah, artinya kekayaan individu yang dimiliki masing-masing genera sangat jauh berbeda. $E=0,6-1$, menunjukkan bahwa pemerataan antar genera relatif seragam atau jumlah individu masing-masing genera relatif sama (Michael, 1994 dalam Hariyati dan Wijaya, 2009).

\section{f. Indeks dominansi (D)}

Menurut Odum (1971) dalam Fachrul (2007), untuk mengetahui adanya dominansi jenis tertentu di perairan dapat digunakan indeks dominansi Simpson dengan persamaan berikut:

$$
\mathbf{D}=\sum\left|\frac{\mathrm{ni}}{\mathrm{N}}\right|^{2}
$$

\section{Keterangan:}

D : Indeks dominansi

ni : Jumlah individuke-i

$\mathrm{N}$ : Jumlah total individu

Indeks dominansi antara 0 - 1 . Nilai indeks dominansi $<0,5$ berarti tidak ada jenis yang mendominansi sedangkan apabila indeks dominansi $>0,5$ berarti ada jenis tertentu yang mendominansi.

\section{g. Analisa hubungan antara kandungan nitrat dan fosfat dengan kelimpahan fitoplankton}

Analisa data yang digunakan untuk mengetahui hubungan antara nitrat dan fosfat dengan kelimpahan fitoplankton adalah dengan analisa regresi linier berganda menggunakan software SPSS 16.

\section{Hasil dan Pembahasan}

\section{Gambaran umum lokasi sampling}

Kabupaten Pekalongan memiliki beberapa sungai salah satunya adalah Sungai Bremi. Sungai Bremi merupakan salah satu anak sungai dari Sungai Sengkarang selain Sungai Meduri yang merupakan salah satu sungai yang terletak dalam wilayah Sungai Pemali-Juana. Sungai Bremi berasal dari saluran pembuang irigasi pada bagian hulu yang masuk dalam wilayah administratif Kabupaten Pekalongan. Alur sungai ini juga melintasi wilayah Kotamadya Pekalongan yang padat (Rahmawati et al, 2008). 
Kabupaten Pekalongan dialiri oleh beberapa sungai, salah satunya adalah Sungai Sengkarang. Sungai Sengkarang memiliki 2 anak sungai yaitu Sungai Meduri dan Sungai Bremi. Tahun 2008 karena beberapa hal aliran Sungai Meduri dan Sungai Bremi diberi pembatas berupa bendungan yang digunakan untuk memisahkan kedua anak sungai tersebut.Sungai Bremi dan Sungai Meduri mulai saat itu memiliki daerah aliran sungai yang berbeda.Sungai Bremi mengalir melewati beberapa desa di Kabupaten Pekalongan sepanjang $\pm 9 \mathrm{~km}$. Sebagian besar sungai ini mengalir di daerah pemukiman warga yang padat penduduk

Kandungan nitrat dan fosfat

Hasil rata-rata pengukuran konsentrasi nitrat dan fosfat adalah sebagai berikut:

Tabel 1. Rata- Rata Pengukuran Nitrat dan Fosfat di Sungai Bremi

\begin{tabular}{cccccccccc}
\hline & & \multicolumn{7}{c}{ Stasiun } & Referensi \\
\cline { 3 - 9 } No. & Konsentrasi & I & SD & II & SD & III & SD & Kategori & $\begin{array}{l}\text { Baku mutu air limbah kelas II } \\
\text { (PP No. 82 Tahun 2001) }\end{array}$ \\
\hline 1. & Nitrat (mg/l) & 0,83 & 0,58 & 0,81 & 0,36 & 0,99 & 0,25 & Rendah & $10 \mathrm{mg} / \mathrm{l}$ \\
2. & Fosfat (mg/l) & 0,90 & 0,47 & 1,35 & 0,23 & 1,20 & 0,30 & Tinggi & $0,02 \mathrm{mg} / 1$ \\
\hline
\end{tabular}

Berdasarkan data dari tabel di atas, rata-rata hasil pengukuran nitrat berkisar antara 0,81 $\mathrm{mgl} / \mathrm{l}-0,99$ $\mathrm{mg} / \mathrm{l}$ sedangkan kisaran hasil pengukuran fosfat adalah $0,90 \mathrm{mg} / \mathrm{l}-1,35 \mathrm{mg} / \mathrm{l}$.

\section{Kelimpahan dan indeks biologi fitoplankton}

Hasil yang diperoleh dari pengamatan fitoplankton di laboratorium jenis dan kelimpahan fitoplankton di perairan Sungai Bremi sebagai berikut:

Tabel 2. Data Kelimpahan dan Indeks Biologi Fitoplankton di Sungai Bremi

\begin{tabular}{clccc}
\hline Kelas & \multicolumn{1}{c}{ Nama Spesies } & $\begin{array}{c}\text { St. I } \\
\text { (ind/l) }\end{array}$ & $\begin{array}{c}\text { St. II } \\
\text { (ind/I) }\end{array}$ & $\begin{array}{c}\text { St. III } \\
\text { (ind/l) }\end{array}$ \\
\hline Bacillariophyceae & Nitzschia sigma & 1427 & 357 & 561 \\
& Nitzschia lanciolata & 127 & 51 & 51 \\
& Nitzschia vitrea & 102 & - & - \\
& Nitzschia filiformis & 382 & 51 & 51 \\
& Bacillaria paradoxa & 204 & 51 & 51 \\
Rhizosolenia delicatula & 51 & - & - \\
& Coscinodiscus lineatus & 25 & 51 & 51 \\
& Coscinodiscus marginatus & - & 25 & - \\
& Navicula radiosa & - & 25 & - \\
& Navicula leptostriate & - & - & 25 \\
Synedra famelica & - & - & 25 \\
Dinophyceae & Thalassiosira rotula & - & - & 51 \\
& Prorocentrum triangulatum & 25 & - & - \\
Cyanophyceae & Peridinium depressum & 76 & 25 & - \\
& Peridinium compactum & 25 & - & 25 \\
& Oscillatoria agardhii & - & 688 & 637 \\
\hline & Kelimpahan (ind/l) & 2444 & 1324 & 1528 \\
& Jumlah spesies & 10 & 9 & 10 \\
& H'(Indekskeanekaragaman) & 1,429 & 1,422 & 1,439 \\
& E (Indeks keseragaman) & 0,620 & 0,642 & 0,625 \\
& D (Indeks dominansi) & 0,377 & 0,349 & 0,363 \\
\hline
\end{tabular}

Berdasarkan hasil pengamatan di atas, fitoplankton yang ditemukan pada saat penelitian di Sungai Bremi dari ketiga stasiun ditemukan 16 spesies dari 3 kelas fitoplankton yaitu Bacillariophyceae, Dinophyceae dan Cyanophyceae. Kelas Bacillariophyceae terdiri atas 12 spesies, kelas Dinophyceae terdiri atas 3 spesies, dan kelas Cyanophyceae terdiri atas 1 spesies. Kelas fitoplankton yang paling sering ditemukan adalah Bacillariophyceae dari beberapa spesies.

Analisa hubungan antara kandungan nitrat dan fosfat dengan kelimpahan fitoplankton

Berdasarkan analisa data dengan menggunakan uji regresi linier berganda maka diperoleh signifikansi sebesar 0,001 yang artinya kurang dari 0,05 sebagai batas probabilitas. Hasil tersebut menunjukkanterdapat hubungan yang nyata antara kandungan nitrat dan fosfat dengan kelimpahan fitoplankton dengan persamaan yang tersaji pada tabel 3 .

Tabel 3. Analisa hubungan antara kandungan nitrat dan fosfat dengan kelimpahan fitoplankton

\begin{tabular}{cccc}
\hline Persamaan & $R$ & $R^{2}$ & Sig \\
\hline$Y=609,548-10,944 X_{1}-265,642 X_{2}$ & 0,774 & 0,599 & 0,001 \\
\hline
\end{tabular}




\section{Parameter pendukung kualitas perairan}

Hasil rata-rata dari pengukuran parameter pendukung kualitas perairan di Sungai Bremi adalah sebagai berikut:

Tabel 4. Rata-Rata Pengukuran Parameter Pendukung Kualitas Perairan di Sungai Bremi

\begin{tabular}{lcccccc}
\hline \multirow{2}{*}{ Parameter Kualitas Air } & \multicolumn{7}{c}{ Stasiun } \\
\cline { 2 - 7 } & I & SD & II & SD & III & SD \\
\hline Suhu Air $\left({ }^{\circ} \mathrm{C}\right)$ & 26,8 & 0,21 & 30,7 & 0,57 & 30,4 & 0,54 \\
Kedalaman $(\mathrm{m})$ & 0,87 & 0,07 & 1,39 & 0,43 & 1,17 & 0,37 \\
Kecerahan $(\mathrm{m})$ & 0,26 & 0,03 & 0,15 & 0,05 & 0,17 & 0,03 \\
Kecepatan Arus (m/s) & 0,019 & 0,001 & 0,047 & 0,01 & 0,073 & 0,02 \\
pH & 4,46 & 0,54 & 3,95 & 0,67 & 3,83 & 0,33 \\
DO $(\mathrm{mg} / \mathrm{l})$ & 2,44 & 0,68 & 1,93 & 0,55 & 2,03 & 0,40 \\
BOD $(\mathrm{mg} / \mathrm{l})$ & 10,71 & 1,82 & 11,49 & 4,63 & 11,38 & 1,92 \\
COD $(\mathrm{mg} / \mathrm{l})$ & 80,21 & 14,19 & 86,28 & 34,75 & 93,16 & 23,75 \\
\hline
\end{tabular}

Data tabel di atas menunjukkan bahwa pengukuran kualitas air memiliki hasil rata-rata yang relatif berbeda pada setiap stasiun. Pada pengukuran suhu perairan diperoleh hasil dengan kisaran $26,8^{\circ} \mathrm{C}-30,7^{\circ} \mathrm{C}$, dan suhu udara berkisar antara $27,6^{\circ} \mathrm{C}-31,6^{\circ} \mathrm{C}$. Hasil pengukuran kedalaman berkisar antara $0,8 \mathrm{~m}-1,39 \mathrm{~m}$, pengukuran kecerahan memiliki kisaran $0,15 \mathrm{~m}-0,26 \mathrm{~m}$, sedangkan kecepatan arus memperoleh hasil yang berkisar antara $0,019 \mathrm{~m} / \mathrm{s}-0,073 \mathrm{~m} / \mathrm{s}$. Pengukuran $\mathrm{pH}$ memperoleh hasil yang berkisar antara3,83 - 4,46 sedangkan hasil pengukuran DO berkisar antara1,93 mg/l - 2,44 mg/l.Pengukuran BOD $_{5}$ memperoleh ratarata hasil dengan kisaran antara 10,71 mg/l - 11,49 mg/l sedangkan pengukuran COD berkisar antara 80,21 $\mathrm{mg} / \mathrm{l}-93,16 \mathrm{mg} / \mathrm{l}$.

\section{Pembahasan \\ Kandungan nitrat dan fosfat di Sungai Bremi \\ a. Nitrat}

Hasil pengujian parameter nitrat di laboratorium dengan menggunakan metode Brusin Sulfat menunjukkan hasil yang berkisar antara $0,81 \mathrm{mg} / \mathrm{l}-0,99 \mathrm{mg} / \mathrm{l}$. Berdasarkan Peraturan Pemerintah No 82 Tahun 2001 tentang Pengelolaan Kualitas Air dan Pengendalian Pencemaran sehubungan dengan klasifikasi dan kriteria baku mutu air limbah kelas II, nilai ambang batas nitrat di perairan adalah $10 \mathrm{mg} / \mathrm{l}$, artinya hasil yang diperoleh jauh di bawah ambang batas yang ditetapkan.

Senyawa nitrat memiliki konsentrasi yang rendah, cukup signifikan di bawah konsentrasi optimal. Berdasarkan sumber lain yaitu Mackentum (1969) dalam Sanaky (2003) menyatakan bahwa kadar nitrat yang optimal bagi pertumbuhan fitoplankton adalah berkisar antara 3,9 ppm - 15,5 ppm, sedangkan kandungan nitrat kurang dari 0,114 ppm akan menyebabkan nitrat menjadi faktor pembatas.

Tinggi rendahnya kandungan nitrat yang terdapat di suatu perairan diperkiran dipengaruhi oleh parameter kualitas perairan, dalam hal ini yang mempengaruhi diperkirakan adalah kandungan oksigen terlarut. Hal ini sesuai dengan Yuliana et al, (2012) bahwa jika oksigen terlarut di perairan rendah maka akan mempengaruhi kegiatan mikroorganisme dalam proses dekomposisi bahan organik. Salah satunya terjadi proses denitrifikasi yaitu proses mikrobiologi dimana ion nitrat dan nitrit diubah menjadi molekul nitrogen $\left(\mathrm{N}_{2}\right)$. Akibatnya kandungan unsur hara yang dapat dimanfaatkan akan menurun.

b. Fosfat

Hasil pengujian parameter fosfat di laboratorium menggunakan metode asam askorbat menunjukkan bahwa kandungan fosfat tertinggi terdapat pada stasiun II yaitu sebesar 1,35 ppm sedangkan hasil terendah diperoleh pada stasiun I yaitu dengan kandungan fosfat sebesar 0,90 ppm. Berdasarkan PP No 82 Tahun 2001 tentang Pengelolaan Kualitas Air dan Pengendalian Pencemaran sehubungan dengan klasifikasi dan kriteria baku mutu air limbah kelas II, nilai ambang batas fosfat di perairan adalah 0,02 mg/l berarti nilai kandungan fosfat yang diperoleh melebihi baku mutu air limbah yang sudah ditetapkan sehingga diduga tidak dianjurkan untuk kegiatan perikanan.

Tinggi rendahnya kadar fosfat pada perairan sungai diduga karena adanya pengaruh dari buangan limbah industri dan limbah domestik dari lingkungan sekitar sungai. Hasil analisa kandungan fosfat yang melebihi ambang batas sehingga namun kisaran konsentrasi fosfat di perairan Sungai Bremi masih dalam batas yang dapat ditolerir oleh fitoplankton. Hal ini sesuai dengan Sanaky (2003) bahwa senyawa fosfat dalam perairan dapat berasal dari sumber alami seperti erosi dari tanah, buangan dari hewan, limbah industri, domestik dan pelapukan tumbuhan atau perairan itu sendiri. Kandungan fosfat yang optimal bagi pertumbuhan fitoplankton berada pada kisaran 0,27 - 5,51 ppm, sedangkan kandungan fosfat kurang dari 0,02 ppm akan menjadikan faktor pembatas.

\section{Fitoplankton dan indeks biologi}

Kompisisi jumlah fitoplankton yang diperoleh dari hasil identifikasi menunjukkan bahwa filum algae yang paling mendominasi pada ketiga stasiun adalah kelas Bacillariaphyceae. Bacillariaphyceae ada pada 
setiap stasiun dengan jumlah yang tidak sedikit bahkan salah satu spesiesnya seperti Nitzchia sigma yang individunya mendominansi dan berbeda cukup signifikan dengan spesies lain. Kelas Bacillariaphyceae memiliki ketahan hidup yang paling baik di perairan yang tercemar. Hal ini sesuai dengan Wetzel (1983) dalam Sanaky (2003) bahwa kelas Bacillariaphyceae merupakan kelas fitoplankton yang memiliki laju pertumbuhan dengan toleransi yang tinggi serta mampu beradaptasi terhadap perubahan lingkungan dan mampu memanfaatkan unsur hara dengan baik dibandingkan dengan spesies lain.

Hasil penghitungan kelimpahan berkisar antara 1324 ind/1 - 2444 ind/l yang artinya kelimpahan dengan kisaran tersebut termasuk dalam kategori kelimpahan yang sedang. Hal ini sesuai dengan Madinawati (2010) yang menyatakan bahwa kelimpahan dengan nilai $<1.000 \mathrm{ind} / \mathrm{l}$ termasuk rendah, kelimpahan antara $1.000-40.000 \mathrm{ind} / \mathrm{l}$ tergolong sedang, dan kelimpahan > 40.000 ind/l tergolong tinggi.Berdasarkan penghitungan kelimpahan perolehan hasil yang tertinggi terdapat pada stasiun I. Kelimpahan fitoplankton di stasiun I lebih tinggi daripada stasiun lain diduga karena konsentrasi fosfat pada stasiun ini lebih rendah dibandingkan dengan stasiun lain. Hal serupa dikatakan oleh Effendi (2003) bahwa kenaikan jumlah sel fitoplankton atau diatom diiringi dengan penurunan kadar fosfat. Fosfor juga merupakan unsur esensial bagi tumbuhan tingkat tinggi dan alga sehingga unsur ini menjadi faktor pembatas bagi tumbuhan dan alga akuatik serta sangat mempengaruhi tingkat produktivitas perairan

Hasil penghitungan menunjukkan bahwa indeks keanekaragaman pada setiap stasiun tidak menunjukkan perbedaan yang berarti. Indeks keanekaragaman berksar antara 1,422-1,439. Berdasarkan Basmi (1999) dalam Fachrul (2007) menyatakan bahwanilai keanekaragaman $1<\mathrm{H}^{\prime}<3$ menunjukkan stabilitas komunitas biota sedang.Hasil pada ketiga stasiun menunjukkan indeks keanekaragamannya sedang karena $1<\mathrm{H}^{\prime}<3$. Hal ini diduga karena tekanaan faktor ekologis perairan yang di sepanjang sungai tersebut merupakan industri rumah tangga pembuatan batik yang diduga mengakibatkan pencemaran.

Nilai indeks keseragaman yang diperoleh dari hasil penghitungan pada ketiga stasiun berada di bawah 1, yaitu berkisar antara 0,620-0,642. Hal ini menunjukkan bahwa kemerataan antar spesies tinggi, artinya kekayaan individu yang dimiliki masing-masing spesies seragam. Hal ini sesuai dengan Michael (1994) dalam Hariyati dan Wijaya (2009), bila nilai E berkisar antara 0,6-1 artinya pemerataan antar spesies relatif seragam atau jumlah individu masing-masing spesies relatif sama.

Hasil penghitungan fitoplankton menunjukkan bahwa indeks dominansi pada ketiga stasiun tidak mengalami perbedaan yang signifikan. Hasil indeks dominansi yang diperoleh yaitu berkisar 0,349 - 0,377. Berdasarkan Odum (1971) dalam Fachrul (2007) nilai indeks dominansi < 0,5 berarti tidak ada jenis yang mendominansi sedangkan apabila indeks dominansi > 0,5 berarti ada jenis tertentu yang mendominansi. Indeks dominasi berkisar antara 0 - 1 apabila semakin rendah mendekati 0 maka diduga tidak terdapat spesies yang mendominasi spesies lainnya walaupun terdapat spesies yang jumlahnya lebih banyak dibandingkan dengan spesies lain

\section{Hubungan antara kandungan nitrat dan fosfat dengan kelimpahan fitoplankton}

Berdasarkan analisa data penelitian nilai signifikansi yang diperoleh dari analisa statistik adalah sebesar 0,001 yang menurut Andriana (2008) berarti terdapat hubungan antar variabel. Nilai r sebesar 0,774, menurut Hasan (2005) nilai $r$ sebesar 0,60 - 0,799 artinya antar variabel satu sama lain memiliki korelasi yang kuat. Hal tersebut menandakan bahwa nitrat, fosfat dan fitoplankton memiliki hubungan yang kuat di perairan Sungai Bremi. Uji $\mathrm{R}^{2}$ yang telah dilakukan memperoleh hasil sebesar 0,599 yang menunjukkan bahwa keberadaan fitoplankton di Sungai Bremi dipengaruhi oleh nitrat dan fosfat sebesar 59,9\% sedangkan 40,1\% lainnya dipengaruhi oleh faktor lain.

Kandungan unsur hara di suatu perairan pada umumnya berkaitan dengan kelimpahan fitoplankton di perairan tersebut. Kandungan unsur hara nitrat dan fosfat sangat mempengaruhi keberadaan fitoplankton.Selama pengamatan, kandungan unsur hara diperoleh memiliki fluktuasi nilai konsentrasi yang seiring dengan kelimpahan fitoplankton. Hal ini diduga disebabkan unsur hara tersebut dimanfaatkan dengan baik untuk pertumbuhan fitoplankton walaupun perairan tersebut termasuk dalam kondisi perairan yang tercemar limbah. Menurut Prescott (1970) dalam Budiardi et al, (2007) kelimpahan komunitas fitoplankton sangat berhubungan dengan kandungan nutrien seperti fosfat, nitrat, silikat, dan hara lainnya. Kandungan nutrien dapat mempengaruhi kelimpahan fitoplankton dan sebaliknya fitoplankton yang padat dapat menurunkan kandungan nutrien dalam air. Perubahan komposisi fitoplankton selanjutnya dapat mempengaruhi komposisi zooplankton dan komunitas planktonsecara keseluruhan dalam suatu ekosistem.

\section{Parameter pendukung kualitas perairan}

Perolehan hasil pengukuran parameter suhu perairan dan udara pada ketiga stasiun bervariasi. Hasil pengukuran yang berbeda-beda ini diduga dipengaruhi oleh faktor waktu pengukuran dan perkiraan cuaca yang tidak menentu. Hal ini sesuai dengan Effendi (2003) yang menyatakan bahwa perbedaan kisaran suhu di masing-masing stasiun pengamatan terjadi karena perbedaan cuaca di saat, sebelum dan sesudah pengukuran. Perbedaan waktu seperti pagi dan siang merupakan hal yang dapat mempengaruhi perbedaan suhu.

Hasil pengukuran arus yang dilakukan pada ketiga stasiun menunjukkan bahwa arus tertinggi yaitu pada stasiun 3 sebesar $0,069 \mathrm{~m} / \mathrm{s}$, dan kecepatan arus yang paling terendah yaitu pada stasiun 1 sebesar 0,019 
$\mathrm{m} / \mathrm{s}$. Hal ini sesuai dengan Andriana (2008), yaitu arus perairan tergolong sangat lambat apabila kecepatannya kurang dari $10 \mathrm{~cm} /$ detik.

Hasil pengukuran $\mathrm{pH}$ pada ketiga stasiun menunjukkan bahwa kondisi perairan memiliki $\mathrm{pH}$ yang rendah atau asam. Nilai $\mathrm{pH}$ yang diperoleh menunjukkan bahwa perairan tersebut tidak terlalu subur dan kurang baik untuk pertumbuhan fitoplankton. Hal ini sesuai dengan Odum (1971) dalam Pirzan dan PongMasak (2008) yang menyatakan bahwa perairan dengan $\mathrm{pH}$ antara 6 - 9 merupakan perairan dengan kesuburan yang tinggi dan tergolong produktif. Nilai $\mathrm{pH}$ sangat mempengaruhi proses biokimiawi perairan, misalnya proses nitrifikasi akan berakhir pada $\mathrm{pH}$ rendah.

Pengukuran kandungan oksigen terlarut mendapatkan hasil yang berbeda-beda namun ketiganya menunjukkan bahwa kandungan oksigen terlarut pada Sungai Bremi rendah. Rendahnya oksigen terlarut di perairan dapat dipengaruhi oleh tingginya suhu di perairan tersebut. Hal ini sesuai dengan Effendi (2003) bahwa semakin tinggi suhu, maka kelarutan oksigen pun semakin berkurang.sumber utama oksigen dalam perairan adalah dari proses fotosintesis. Semakin subur suatu perairan akan semakin banyak fitoplankton yang hidup di dalamnya dan akhirnya akan meningkatkan pasokan oksigen terlarut dalam air.

Pengukuran kedalaman pada ketiga stasiun mendapatkan hasil yang relatif berbeda. Keadaan ini dapat mempengaruhi adanya perbedaan intesitas cahaya yang masuk ke dalam perairan. Hal ini sesuai dengan Sukarno (1981) dalam Ulqodry et al, (2007) bahwa kedalaman perairan juga mempengaruhi penetrasi sinar matahari ke dalam perairan sehingga secara tidak langsung akan mempengaruhi kebutuhan oksigen dan pertumbuhan organisme bentik.

Hasil pengukuran kecerahan menunjukkan bahwa perolehan tertinggi terdapat pada stasiun I dan terendah pada stasiun III. Kecerahan pada suatu perairan berhubungan erat dengan kedalaman. Perairan dengan kecerahan yang baik akan memberi pengaruh yang baik terhadap daya tembus sinar matahari yang dapat berguna bagi proses fotosintesis. Hal ini sesuai dengan Fachrul (2007) yang menyatakan bahwa semakin dalam penetrasi cahaya kedalam perairan menyebabkan semakin besar daerah dimana proses fotosintesis dapat berlangsung.

Hasil pengujian nilai BOD di laboratorium dengan kisaran 10,71 mg/l - 11,49 mg/l menunjukkan bahwa perolehan nilai BOD pada ketiga stasiun bervariasi. Nilai BOD tertinggi dari hasil pengukuran terdapat pada stasiun III, sedangkan terendah diperoleh pada stasiun I. Berdasarkan Peraturan Pemerintah No. 82 tahun 2001 baku mutu nilai BOD di perairan tawar adalah $6 \mathrm{mg} / \mathrm{l}$ yang berarti nilai BOD pada ketiga stasiun melebihi ambang batas yang telah ditentukan. Nilai BOD pada perairan mempengaruhi kebutuhan oksigen bagi organisme di perairan. Tinggi rendahnya nilai BOD mempengaruhi keberadaan organisme dan dapat mengindikasikan terjadinya pencemaran.

Hasil pengujian laboratorium pada parameter COD menunjukkan bahwa hasil tertinggi diperoleh pada stasiun 3 terendah diperoleh pada stasiun 1. Berdasarkan baku mutu air dalam Peraturan Pemerintah No. 82 tahun 2001, nilai COD yang diperkenankan maksimum $50 \mathrm{mg} / \mathrm{l}$. Hasil pengukuran rata-rata berkisar antara $80,21 \mathrm{mg} / \mathrm{l}-93,16 \mathrm{mg} / \mathrm{l}$ yang berarti melebihi baku mutu yang telah ditentukan. Keadaan tersebut dapat mengakibatkan pencemaran pada suatu perairan karena limbah industri. Hal ini sesuai dengan Yudya (1991) yang menyatakan bahwa nilai COD digunakan untuk mengetahui tingkat pencemaran air limbah dari kegiatan industri. Nilai COD perlu diketahui dalam pendugaan pencemaran hal ini disebabkan

\section{Kesimpulan}

Kesimpulan yang diperoleh dari hasil penelitian mengenai Hubungan antara kandungan nitrat dan fosfat dengan kelimpahan fitoplankton di Sungai Bremi adalah sebagai berikut:

1. Kandungan nitrat di perairan Sungai Bremi yang diperoleh adalah berkisar antara 0,81 mg/l - 0,99 mg/l. Konsentrasi nitrat dengan kisaran tersebut tergolong rendah

2. Kandungan fosfat di perairan Sungai Bremi yang diperoleh adalah berkisar antara 0,90 mg/l - 1,35 mg/l. Konsentrasi fosfat dengan kisaran tersebut termasuk dalam konsentrasi fosfat yang tinggi namun masih dalam batas yang dapat ditolerir oleh fitoplankton

3. Kelimpahan fitoplankton di perairan Sungai Bremi diperoleh hasil penghitungan yang berkisar antara $1324 \mathrm{ind} / \mathrm{l}$ - $2444 \mathrm{mg} / \mathrm{l}$ yang artinya kelimpahan fitoplankton di Sungai Bremi termasuk dalam kategori sedang

4. Hubungan antara kandungan nitrat dan fosfat dengan kelimpahan fitoplankton dilihat dari perolehan nilai r sebesar 0,774 menunjukkan bahwa terdapat hubungan yang erat

\section{Ucapan Terima Kasih}

Ucapan terima kasih ditujukan kepada Ir. Siti Rudiyanti, M.Si dan Drs. Mustofa Niti Suparjo, M.Si atas bimbingannya dalam penyusunan jurnal ini. 


\section{DAFTAR PUSTAKA}

Andriana, W. 2008. Keterkaitan Struktur Komunitas Makrozoobenthos Sebagai Indikator Keberadaan Bahan Organik di Perairan Hulu Sungai Cisadane Bogor, Jawa Barat [Skripsi]. Institut Pertanian Bogor. Bogor.

Budiardi, T., I. Widyaya, dan D. Wahjuningrum. 2007. Hubungan Komunitas Fitoplankton dengan Produktivitas Udang Vaname (Litopenaeus vannamei) di Tambak Biocrete. Departemen Budidaya Perairan Fakultas Perikanan dan Ilmu Kelautan, Institut Pertanian Bogor. Jurnal Akuatik Indonesia, 6 (2): $119-125$.

Effendi, H. 2003. Telaah Kualitas Air Bagi Pengelolaan Sumberdaya dan Lingkungan Perairan. Kanisius. Yogyakarta.

Elfinurfajri, F. 2009. Struktur Komunitas Fitoplankton serta Keterkaitannya dengan Kualitas Perairan di Lingkungan Tambak Udang Intensif. [Skripsi]. Fakultas Perikanan dan Ilmu Kelautan, Institut Pertanian Bogor. Bogor.

Fachrul, M. F. 2007. Metode Sampling Bioekologi. Bumi Aksara. Jakarta.

Hariyati, R. dan Wijaya, T. S. 2009. Struktur Komunitas Fitoplankton sebagai Bio Indikator Kualitas Perairan Danau Rawapening Kabupaten Semarang Jawa Tengah. Laboratorium Ekologi dan Biosistematika Jurusan Biologi F. MIPA UNDIP, Semarang. Semarang.

Hasan, M. I. 2005. Pokok-pokok Materi Statistik 1 (Deskripsi Deskriptif). Bumi Aksara. Jakarta

Madinawati. 2010. Kelimpahan dan Keanekaragaman Plankton di Perairan Laguna Desa Tolongano Kecamatan Banawa Selatan. Media Litbang Sulawesi Tengah. Media Litbang Sulteng, 3 (2): 119 123.

Pirzan, A. M., dan P. R. Pong-Masak. 2008. Hubungan Keragaman Fitoplankton dengan Kualitas Air Kabupaten Takalar, Sulawesi Selatan. Balai Riset Perikanan Budidaya Air Payau, Maros 90512. Biodiversitas, 9 (3): 217 - 221.

Rahmawati, I. P., dan A. Nunik. 2008. Sistem Pengendalian Banjir Sungai Sengkarang (Normalisasi Sungai) (Flood Control System Of Sengkarang River). [Tesis]. Fakultas Teknik Universitas Diponegoro. Semarang.

Republik Indonesia. 2001. Peraturan Pemerintah No. 82 Tahun 2001 Tentang Pengelolan Kualitas Air dan Pengendalian Pencemaran Air.

Risamasu, Fonny J.L, dan H. B. Prayitno. 2011. Kajian Zat Hara Fosfat, Nitrit, Nitrat dan Silikat di Perairan Kepulauan Matasiri, Kalimantan Selatan. Pusat Penelitian Oseanografi-LIPI. 16(3): 135-142.

Sanaky, A. 2003. Struktur Komunitas Fitoplankton Serta Hubungannya dengan Parameter Fisika Kimia Perairan di Muara Sungai Bengawan Solo Ujung Pangkah Gresik Jawa Timur. [Skripsi]. Institut Pertanian Bogor. Bogor.

Suharto, B. G. dan A. Miryanti. 2003. Perekayasaan Metodologi Penelitian. Penerbit Andi. Yogyakarta.

Toshihiko, M. 1964. Illustration of The Freshwater Plankton of Japan. Hoikusha Publishing Co. Ltd. Japan $987 \mathrm{p}$.

Ulqodry, T.Z., Yulisman, M. Syahdan, dan Santosa. 2010. Karakteristik dan Sebaran Nitrat Fosfat dan Oksigen Terlarut di Perairan Karimunjawa, Jawa Tengah. Universitas Sriwijaya. Lampung. Jurnal Penelitian Sains, 13 (1 D): 13109.

Yudya, B. 1991. Karakteristik Komunitas Makrozoobenthos di Muara Sungai Citarum dalam Hubungannya dengan Pendugaan Pencemaran Perairan di Teluk Jakarta. [Skripsi]. Fakultas Perikanan dan Ilmu Kelautan Institut Pertanian Bogor. Bogor.

Yuliana, E. M. Adiwilaga, E. Harris, dan N. T. M. Pratiwi. 2012. Hubungan Antara Kelimpahan Fitoplankton dengan Parameter Kimiawi Perairan di Teluk Jakarta. Institut Pertanian Bogor, Jawa Barat. Jurnal Akuatika, 3(2): 169-179. 